\title{
23. PHYSICAL PROPERTIES OF SEDIMENTARY ENVIRONMENTS IN OCEANIC HIGH (SITE 658) AND LOW (SITE 659) PRODUCTIVITY ZONES ${ }^{1}$
}

\author{
Jürgen Mienert ${ }^{2}$ and Peter Schultheiss ${ }^{3}$
}

\begin{abstract}
Understanding the changes and characteristics of sediment physical properties beneath coastal upwelling and nonupwelling areas was one of the major objectives in physical property studies on Leg 108 drilling. Increased biogenic silica concentrations in sediments beneath the upwelling area (Hole 658A) cause a low average grain density $\left(<2.4 \mathrm{~g} / \mathrm{cm}^{3}\right)$, low wet-bulk density $\left(<1.6 \mathrm{~g} / \mathrm{cm}^{3}\right)$, and low shear strength $(<60 \mathrm{kPa})$.

Sediments from the nonupwelling area (Hole 659A) have higher average carbonate concentrations $(40 \%-90 \%)$ and reflect a steady increase in wet-bulk density (decrease in porosity) with sub-bottom depth $\left(0.12 \mathrm{~g} / \mathrm{cm}^{3} / 100 \mathrm{~m}\right)$. Organic carbon concentrations, which are high at the upwelling site $(<3.5 \%)$ and very low at the nonupwelling site $(<0.4 \%)$, have no significant influence $(R=<0.4)$ on the physical properties of sediment.

The most substantial difference between the upwelling (Hole 658A) and the nonupwelling area (Hole 659A) is the presence of the high biogenic silica concentration (Hole 658A) that marks a Pliocene-Pleistocene interval in which biogenic gas concentrations drastically increase at sub-bottom depths greater than $25 \mathrm{~m}$. The distinct changes in the sediment physical properties observed beneath areas of intense upwelling should provide large enough impedance contrasts for mapping the distribution of upwelling cells in sediments by acoustic methods.
\end{abstract}

\section{INTRODUCTION}

One of the most important oceanic features for sedimentation off the northwest African continental margin is a coastal upwelling cell. Such cells are characterized by high biological productivity and a high biogenic-sediment flux to the ocean floor beneath the cells (Sarnthein et al., 1982). Surface sediments beneath coastal upwelling areas of the continental margin typically contain high organic carbon contents (Suess and Müller, 1980 ), resulting in a high water content but low wet-bulk density (Busch and Keller, 1981; Keller, 1982, 1983). The high organic carbon contents are due to high biological surface productivity, which is due, in turn, to a high supply rate of nutrients provided by the upwelling of cold, nutrient-rich water.

The history and distribution of coastal upwelling cells is recorded in the sediments through changes in concentrations of organic and biogenic-siliceous matter (Müller et al., 1983). Our long-term goal is to determine (1) whether the physical and acoustic sediment properties beneath areas of intense coastal upwelling are unique, and (2) whether upwelling cells can possibly be monitored in sediments by acoustic methods.

In this paper we compare the sediment physical and acoustical properties (wet-bulk density, water content, porosity, shear strength, and compressional wave velocity) of an upwelling and a nonupwelling area, both located at the northwest African continental margin. We chose Ocean Drilling Program (ODP) Holes 658A and 659A, which lie in a hemipelagic to pelagic depositional environment. Hole $659 \mathrm{~A}$, located on the Cape Verde Plateau, is a reference site for the nonupwelling area. Hole $658 \mathrm{~A}$, the reference site for the upwelling area, lies beneath a permanent upwelling cell off Cap Blanc and represents one of the largest coastal upwelling areas of the world ocean.

\footnotetext{
${ }^{1}$ Ruddiman, W., Sarnthein, M., et al., 1989. Proc. ODP, Sci. Results, 108: College Station, TX (Ocean Drilling Program).

${ }^{2}$ Woods Hole Oceanographic Institution, Woods Hole, MA 02543 (present address: GEOMAR, Forschungszentrum für Marine Geowissenschaften, Wischhofstrasse 1-3, D-2300 Kiel, Federal Republic of Germany).

${ }^{3}$ Institute of Oceanographic Sciences, Wormley, Godalming, Surrey GU8 5UB, United Kingdom.
}

\section{STUDY AREA AND SEDIMENT COMPOSITION}

Hole $658 \mathrm{~A}$ is located at a water depth of $2263 \mathrm{~m}$ on the continental slope of northwest Africa, $160 \mathrm{~km}$ west from Cap Blanc, at $20^{\circ} 44.95^{\prime} \mathrm{N}, 18^{\circ} 34.85^{\prime} \mathrm{W}$ (Fig. 1). It is positioned between two major canyon systems, which act as principal conduits for the downslope transport of shallow-water sediment to the continental rise (Shipboard Scientific Party, 1988a). This position minimizes the potential for disturbance of the hemipelagic sediment record by turbidity currents. The amount of sediment supplied, therefore, is mainly determined by the intensity of the northern trade winds, a driving force for the transport of eolian dust and a motor for the upwelling cell that, in turn, drives the biological productivity and thus the biogenic sediment flux (Thiede et al., 1982; Sarnthein et al., 1982). Changes in the biogenic and/or terrigenous sediment flux result in distinct changes in lithology.

Hole $658 \mathrm{~A}$ consists of three hemipelagic sediment units that are early Pliocene to Holocene in age (Ruddiman, Sarnthein, et al., 1988). Unit I (0-91.2 meters below seafloor [mbsf], lowermost Brunhes to Holocene) consists of gray to olive gray nannofossil ooze grading downward into a diatomnannofossil ooze. Minor but variable amounts of quartz, foraminifers, and biogenic silica occur throughout this sediment column. Carbonate content is less than $69 \%$, and anorganic carbon content, less than 2.3\%. Unit II (91.2-233.9 mbsf, late Pliocene to early Pleistocene) consists of olive to olive gray nannofossil ooze interbedded with mixtures of siliceous and siliciclastic sediment. It contains a high content of biogenic opal, up to $3.3 \%$ in organic carbon, and a decreased carbonate content from $19 \%$ to $50 \%$. Unit III (233.9300.4 mbsf, early Pliocene to late Pliocene) consists of gray to dark gray nannofossil-bearing mud to nannofossil ooze. Although this sediment contains only minor amounts of biogenic silica, it has up to $3 \%$ in organic carbon. Carbonate content varies between $10 \%$ and $45 \%$. Sediment disturbance due to drilling processes and degassing is slight to moderate in Unit I, slight in Unit II, and moderate to great in Unit III (Shipboard Scientific Party, 1988a). Therefore, the samples for physical property measurements were only selected from intervals of undisturbed sediments. 

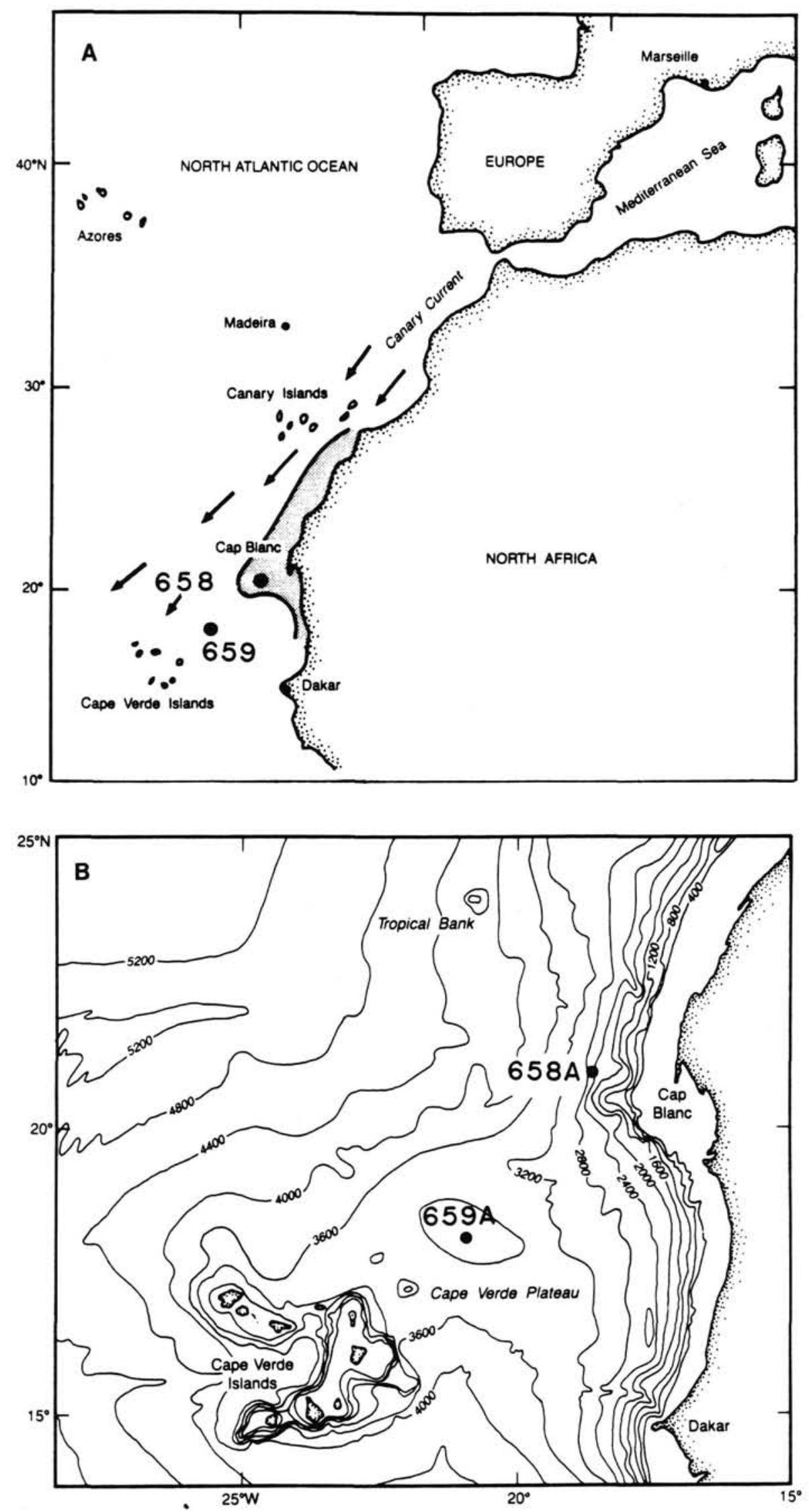

Figure 1. A. Location of Site 658 (upwelling) and Site 659 (nonupwelling). Arrows mark the Canary current system; stippled areas mark regions of strong Pliocene to Pleistocene upwelling. B. Bathymetric map (from E. Uchupi, unpubl. data) with the location of Holes 658A and 659A (contour in meters). 
Hole $659 \mathrm{~A}$ is located at a water depth of $3070 \mathrm{~m}$ on top of the Cape Verde Plateau near the northwest African continental margin at $18^{\circ} 04.63^{\prime} \mathrm{N}, 21^{\circ} 01.57^{\prime} \mathrm{W}$ (Fig. 1). This position is, as at Hole $658 \mathrm{~A}$, not thought to be affected by turbidity currents and contains a continuous record of pelagic carbonate sediment (Shipboard Scientific Party, 1988b). Its sediment composition is influenced by biological productivity in the cold water front of the Canary Eastern boundary current and transport of eolian sediment from the Sahara Desert (Sarnthein et al., 1982; Stein and Sarnthein, 1984). The sediment column shows distinct cyclical changes from white-colored carbonate-rich to brownish carbonate-poor sediment. The Neogene sediment section is $273.8 \mathrm{~m}$ thick and consists of two major lithologic units. Unit I (0-159.8 mbsf, early Pliocene to Holocene) shows a nannofossil ooze interbedded with foraminifer-nannofossil ooze. Carbonate contents vary from $40 \%$ to $90 \%$. Unit II (159.8-273.8 mbsf, Miocene to early Pliocene) consists of a nannofossil ooze interbedded with silty nannofossil ooze. Carbonate contents vary from about $10 \%$ to $70 \%$. Organic carbon content $(<0.4 \%)$ is distinctly lower than at the upwelling area (Hole 658A). The sediment disturbance was minor throughout each lithologic unit, and no degassing was observed.

\section{METHODS}

Physical and acoustical properties of sediments were determined in the ship's laboratory at 1 atm pressure and a temperature of approximately $22^{\circ} \mathrm{C}$. We attempted to measure undisturbed samples only. The results presented in this paper include wet-bulk density, water content, porosity, shear strength, and compressional wave $(P$-wave) velocity.

Wet-bulk density, water content, grain density, and porosity were determined by using gravimetric techniques, that is, the volume of solid methods outlined by Hamilton (1971) and Boyce (1973, 1976).
The accuracy of the measurements depends on the shipboard weighing, which has a precision of $\pm 0.02 \mathrm{~g}$. The resulting estimated precision of wet-bulk density is $\pm 0.02 \mathrm{~g} / \mathrm{cm}^{3}$ and is $\pm 1 \%$ (absolute) for water content and porosity.

Sediment volume was measured with a pycnometer. It measures the volume of helium gas injected into the pore space of a sample. It allows calculation of the total pore space of sediments (i.e., both interand intrapore space). The samples were dried at $100^{\circ} \mathrm{C}$ and weighed before dry volume was measured. The estimated precision of the calculated grain density values is $\pm 0.02 \mathrm{~g} / \mathrm{cm}^{3}$.

Hand-held "Torvane" shear strength measurements were performed on slightly to moderately consolidated sediments down to a depth of 300 mbsf. Because much of the cored material at Hole 658A had undergone disturbance due to degassing of the sediment, the shear strength profiles are not always indicative of formation shear strength. The problem of gas also precluded measurements of complete $P$-wave velocity profiles.

The $P$-wave velocities were measured with both the Hamilton Frame (Boyce, 1976) and the $P$-wave logger. These instruments have a propagation frequency of 400 and $500 \mathrm{kHz}$, respectively. The $P$-wave logger records the time delay of a pulse that travels, parallel to sediment bedding, through a liner filled with sediment (Schultheiss and McPhail, this vol.). The Hamilton Frame records the time delay of a pulse either in a vertical or a horizontal direction. In gas-rich sediments, the attenuation of the sound pulse was so high that neither the Hamilton Frame nor the $P$-wave logger could obtain accurate results. In gas-free sediments, however, the estimated precision is $\pm 2 \%$ for the Hamilton Frame and $\pm 1 \%$ for the $P$-wave logger. The precision of the $P$-wave logger is based on the assumption that during the whole-core logging the liner is completely filled with sediment.

\section{RESULTS AND DISCUSSION}

The most significant differences between upwelling (Hole $658 \mathrm{~A}$ ) and nonupwelling (Hole 659A) areas are seen in (1) the sedimentological record of organic carbon (Figs. 2 and 3); (2)

\section{$658 A$}

\section{UPWELLING SITE}

\section{CARBONATE CONTENT (\%)}

ORGANIC CARBON (\%)
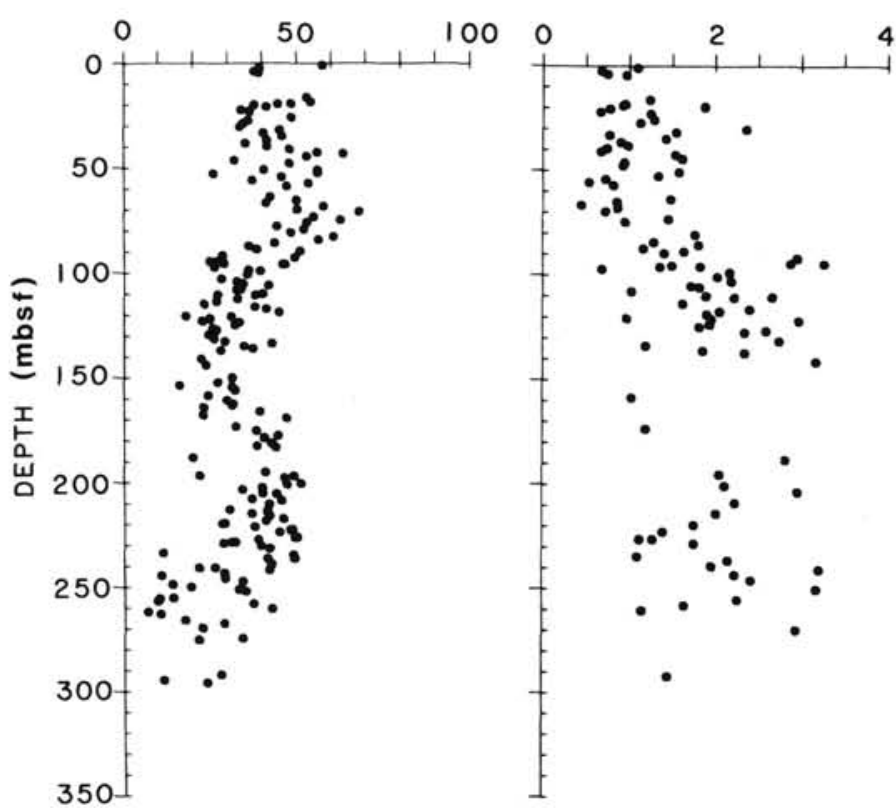

ORGANIC CARBON (\%)

CARBONATE CONTENT (\%)

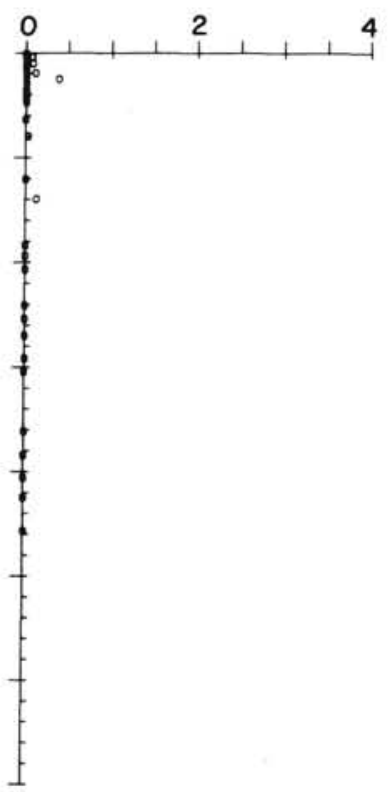

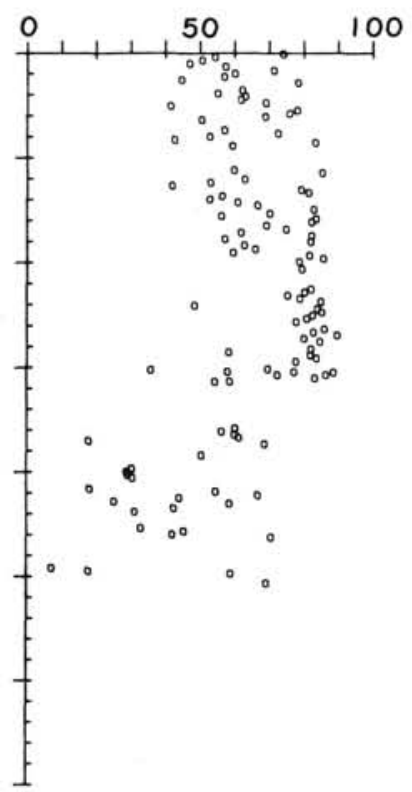

Figure 2. Carbonate content and organic carbon content vs. depth of the upwelling (Hole 658A) and the nonupwelling area (Hole 659A). Note the low organic carbon values at the nonupwelling area. 

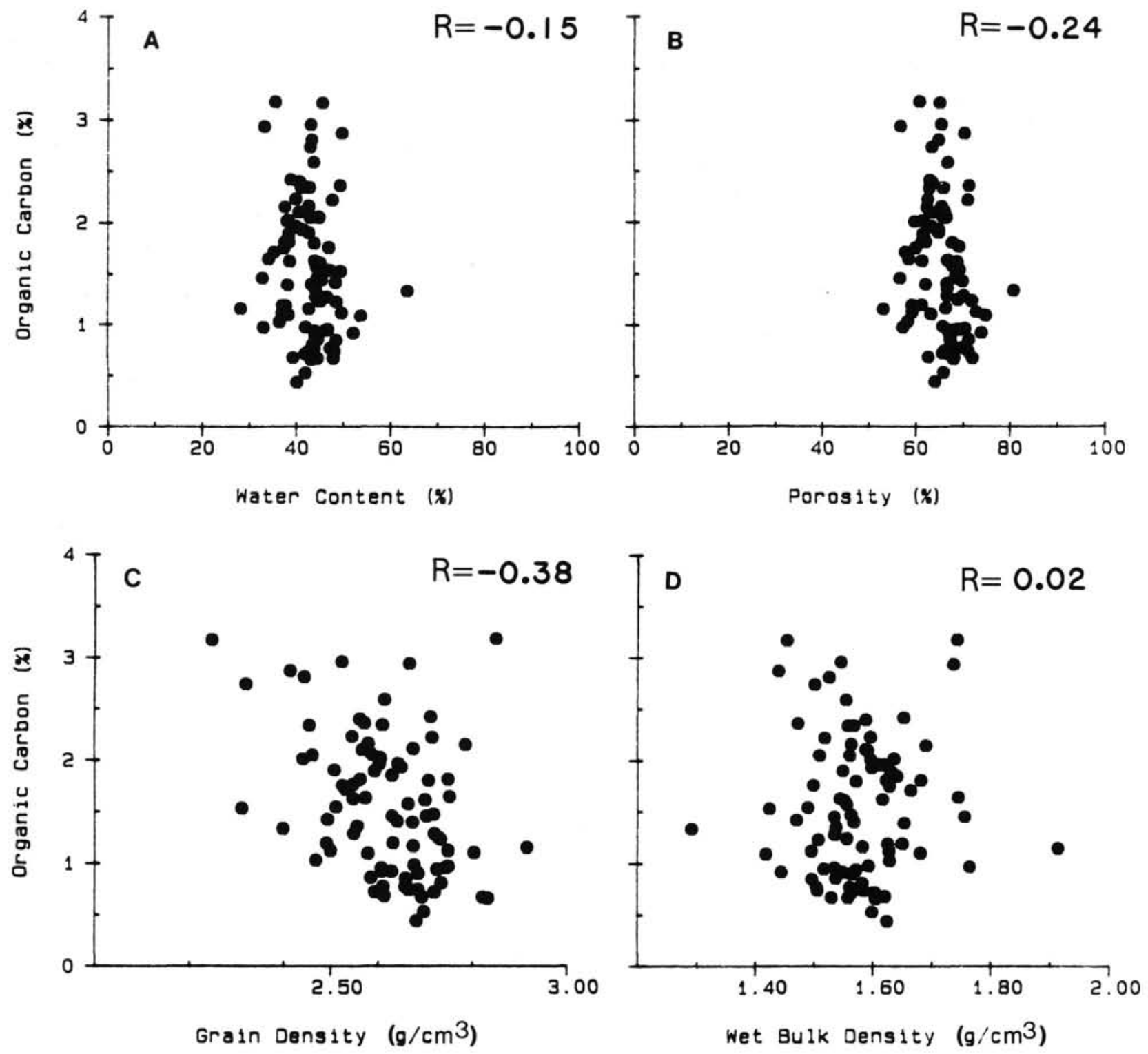

Figure 3. Relationship of water content (A), porosity (B), grain density (C), and wet-bulk density (D) to organic carbon content at the upwelling site (Hole 658A). Sediments (0-275 mbsf) are of Pliocene to Holocene age. Correlation coefficients are shown for each plot.

the physical property record of grain density (Figs. 4 and 5); and (3) the presence of biogenic gas in organic-rich sediment (Figs. 6 and 7).

\section{Organic Carbon and Geotechnical Properties}

The sedimentological record (Shipboard Scientific Party, 1988a) of the upwelling area (Hole 658A) shows high organic carbon contents, ranging from $0.4 \%$ to $3.3 \%$ (Fig. 2). In contrast, low values of $<0.4 \%$ prevail at the nonupwelling area (Hole 659A). Ideally, this pattern shows what one would expect in upwelling and nonupwelling areas, that is, high values of organic carbon at upwelling and low values at nonupwelling sites. Exceptions from this general pattern might occur where the depositional environment has high supply rates of terrigenous organic matter; for example, from eolian and/or fluvial sources.

While eolian sediments influence the sediment composition at both sites, only the upwelling site (Hole 658A) has high organic carbon contents (Fig. 2). Thus, oceanic productivity probably is the major source of high organic carbon contents in sediments at Hole 658A. High values of organic carbon $(1 \%-3.3 \%)$ and low values of carbonate content $(0 \%-50 \%)$ exist below 90 mbsf at Hole 658A, whereas low values of organic carbon $(0.4 \%-2 \%)$ and high values of carbonate content $(25 \%-70 \%)$ exist above 90 mbsf. Such a relationship was not observed at the nonupwelling site (Hole 659A), where carbonate content decreases distinctly below $150 \mathrm{mbsf}$ without a corresponding increase in organic carbon.

The relationships between organic carbon and physical properties of sediments (i.e., water content, porosity, grain density, and wet-bulk density) for Site 658A are shown in Figure 3 . The physical properties show no significant correlation $(R=<0.4)$ with changes in organic carbon content $(0 \%-3.3 \%)$. This is somewhat surprising because organic carbon is known to have a profound effect on geotechnical properties of sediments even at values as low as $2 \%$ (e.g., Busch and Keller, 1981; Keller, 1982; Booth and Dahl, 1985). For example, laboratory experiments in which texture and 


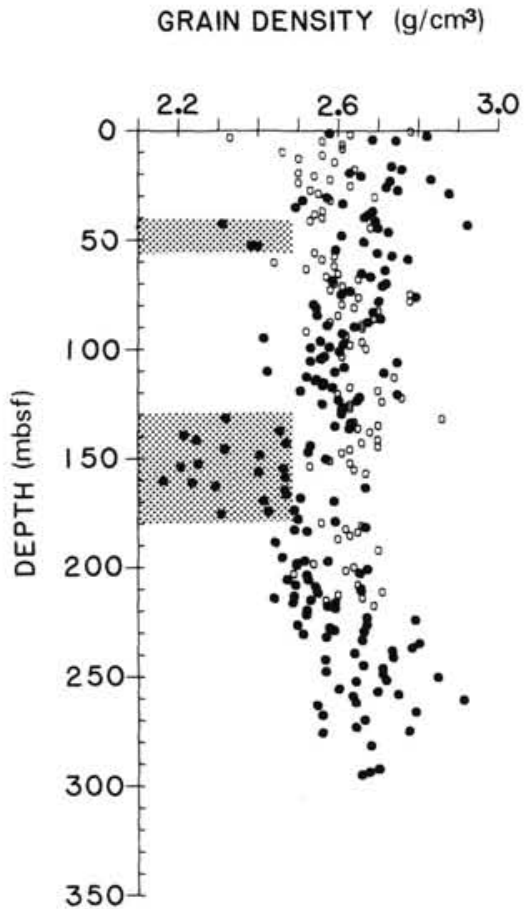

Figure 4. Grain density vs. depth for the upwelling (solid circles, Hole $658 \mathrm{~A}$ ) and the nonupwelling area (open circles, Hole 659A). The most distinct changes in grain density are marked by stippled areas. composition of sediments, except for organic carbon content $(0 \%-3.5 \%)$, were held constant show a clear positive correlation $(R=>0.90)$ between organic carbon and water content and a clear negative correlation $(R=>0.90)$ between organic carbon and grain density (Booth and Dahl, 1985).

The same relationship also applies in the upper $2 \mathrm{~m}$ of continental slope deposits off Peru, where coastal upwelling contributes significantly to an abnormally high organic carbon concentration of up to $20 \%$ (Keller, 1982). No such relationship was found in sediments at Hole $658 \mathrm{~A}$ beneath the up-welling cell off northwest Africa. Here, consolidation of sediments with increased burial depth and dilution of biogenic sediments by siliciclastic sediments possibly overprint the interrelationships observed in surface sediments off Peru.

\section{Grain Density and Sediment Composition}

The most remarkable features at the upwelling area (Hole $658 \mathrm{~A})$ are low average grain density values $\left(2.1-2.4 \mathrm{~g} / \mathrm{cm}^{3}\right)$, which occur between 40 and 55 mbsf and between 120 and 180 mbsf (Fig. 4); that is, between approximately 0.3 and $0.4 \mathrm{Ma}$ and between 1.8 and $2.4 \mathrm{Ma}$. The distinct changes in the grain density of sediments beneath the upwelling cell off northwest Africa (Hole 658A) are not seen in sediments at the nonupwelling area (Hole 659A) (Fig. 4). Low grain density intervals at Hole $658 \mathrm{~A}$ indicate the presence of appreciable amounts of biogenic silica (pure biogenic silica has very low grain density values: from 2.1 to $2.3 \mathrm{~g} / \mathrm{cm}^{3}$, as per Baas Becking and Moore, 1959 , and from 1.70 to $2.05 \mathrm{~g} / \mathrm{cm}^{3}$, as per Hurd and Theyer, 1977) (Mienert et al., 1988).
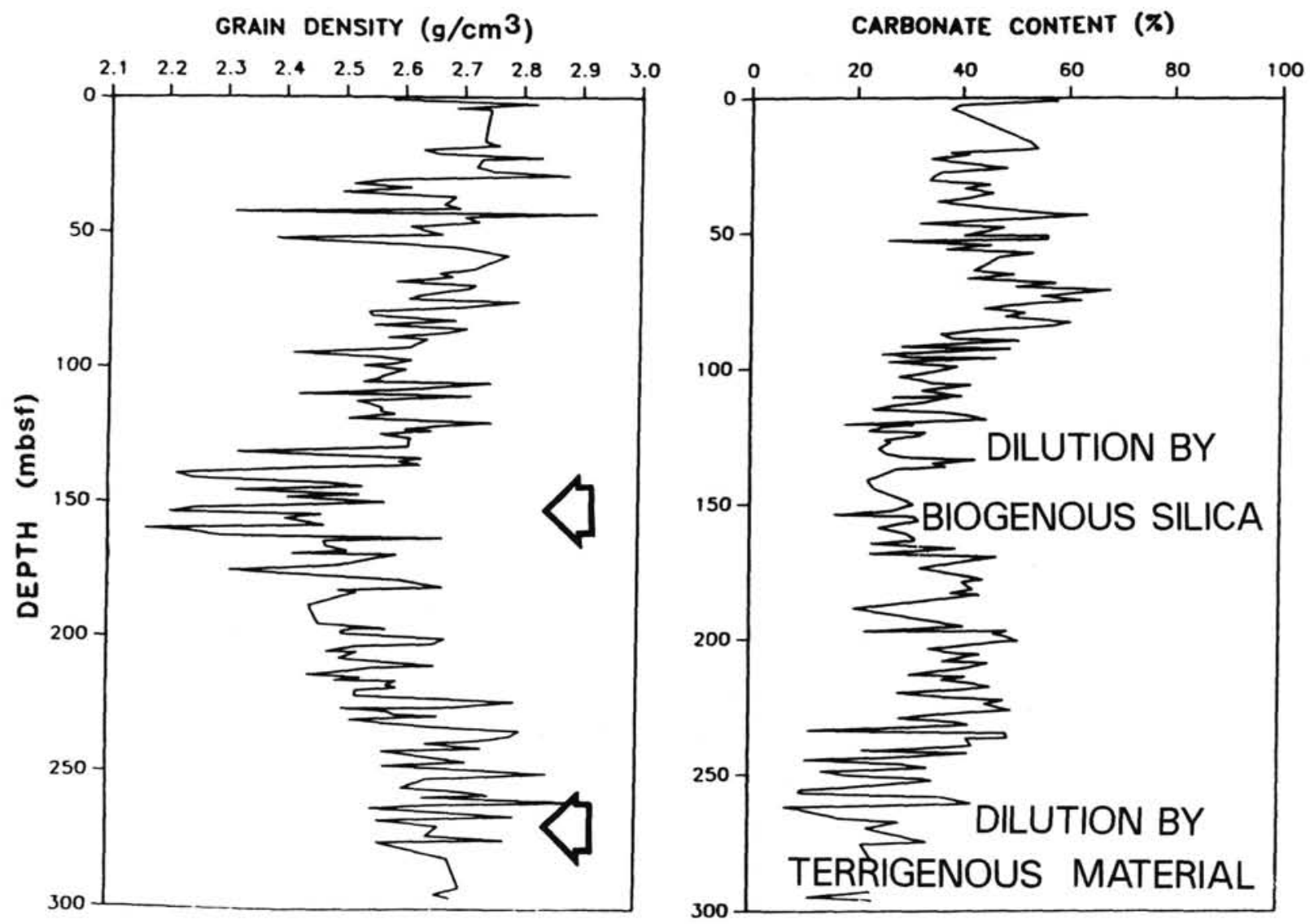

Figure 5. Grain density and carbonate content vs. depth at Hole 658A. A low grain density and a low carbonate content indicate dilution of carbonate by biogenous silica, whereas a high grain density and a low carbonate content indicate dilution of carbonate by terrigenous material. 
P-WAVE VELOCITY $(\mathrm{km} / \mathrm{s})$

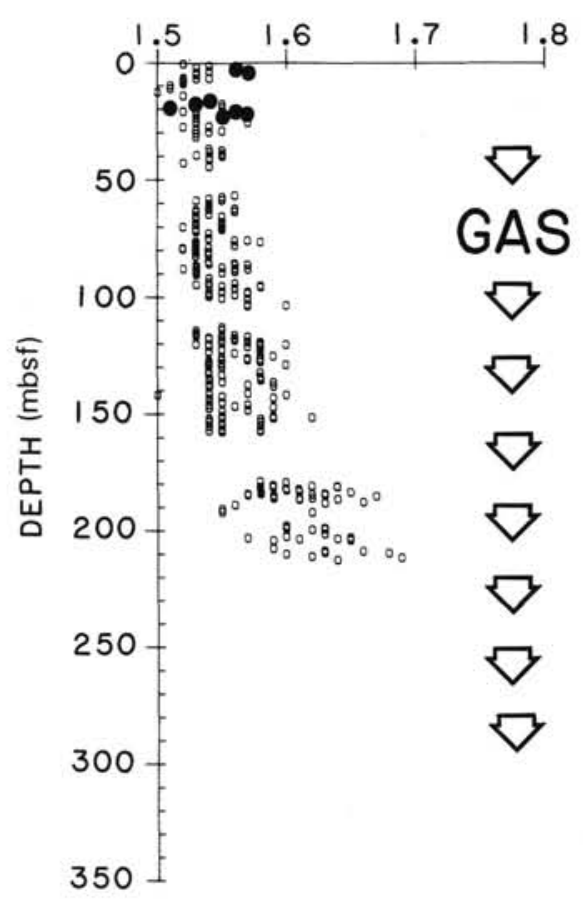

Figure 6. Compressional wave velocity vs. depth for the upwelling (solid circles, Hole 658A) and the nonupwelling area (open circles, Hole 659A). Arrows mark the presence of biogenic gas in sediment cored at the upwelling area (Hole 658A). At Hole 659A no gas was observed.
By comparing the grain density with the carbonate content record (Fig. 5), one can qualitatively determine whether low contents of biogenic carbonate are due to (1) dilution by biogenic silica or (2) dilution by terrigenous material. Low values of carbonate content $(<50 \%)$ and low values of grain density $\left(<2.6 \mathrm{~g} / \mathrm{cm}^{3}\right)$ indicate dilution by biogenous silica, while low values of carbonate and high values of grain density $\left(>2.6 \mathrm{~g} / \mathrm{cm}^{3}\right)$ indicate dilution by terrigenous material (Fig. 5). The mean grain density value of $2.59 \mathrm{~g} / \mathrm{cm}^{3}$ at Hole $658 \mathrm{~A}$ is 0.3 $\mathrm{g} / \mathrm{cm}^{3}$ below the mean value calculated for Hole 659A ( 2.62 $\mathrm{g} / \mathrm{cm} 3$ ), and significantly below the average value for pure carbonate or clay of $2.65-2.75 \mathrm{~g} / \mathrm{cm}^{3}$. The low grain density may indicate the presence of minor amounts of biogenic silica within most of the sediment beneath the upwelling cell.

\section{Biogenic Gas and Acoustic Properties}

The most substantial difference between the upwelling and the nonupwelling site is the presence of gas in sediments beneath the upwelling cell (Hole 658A), which is apparent in sediments at about $25 \mathrm{mbsf}$ and deeper (Fig. 6). In depths greater than $25 \mathrm{mbsf}$, the attenuation of the velocity was so high in sediments of Hole $658 \mathrm{~A}$ that it prevented accurate $P$-wave velocity measurements. At present, it is unknown whether gas exists in situ in a free state or, due to the hydrostatic pressure, in a soluble state. An answer may be sought in the seismic records, which show a bowl-shaped reflector sequence directly beneath a zone of acoustic transparency (stippled zone, Fig. 7). The bowl-shaped reflector implies that either (1) the sedimentation rate drastically increased, which led to a possible downward migration of the reflector sequence, or (2) the $P$-wave velocity dramatically decreased due to the presence of gas causing the same pattern.

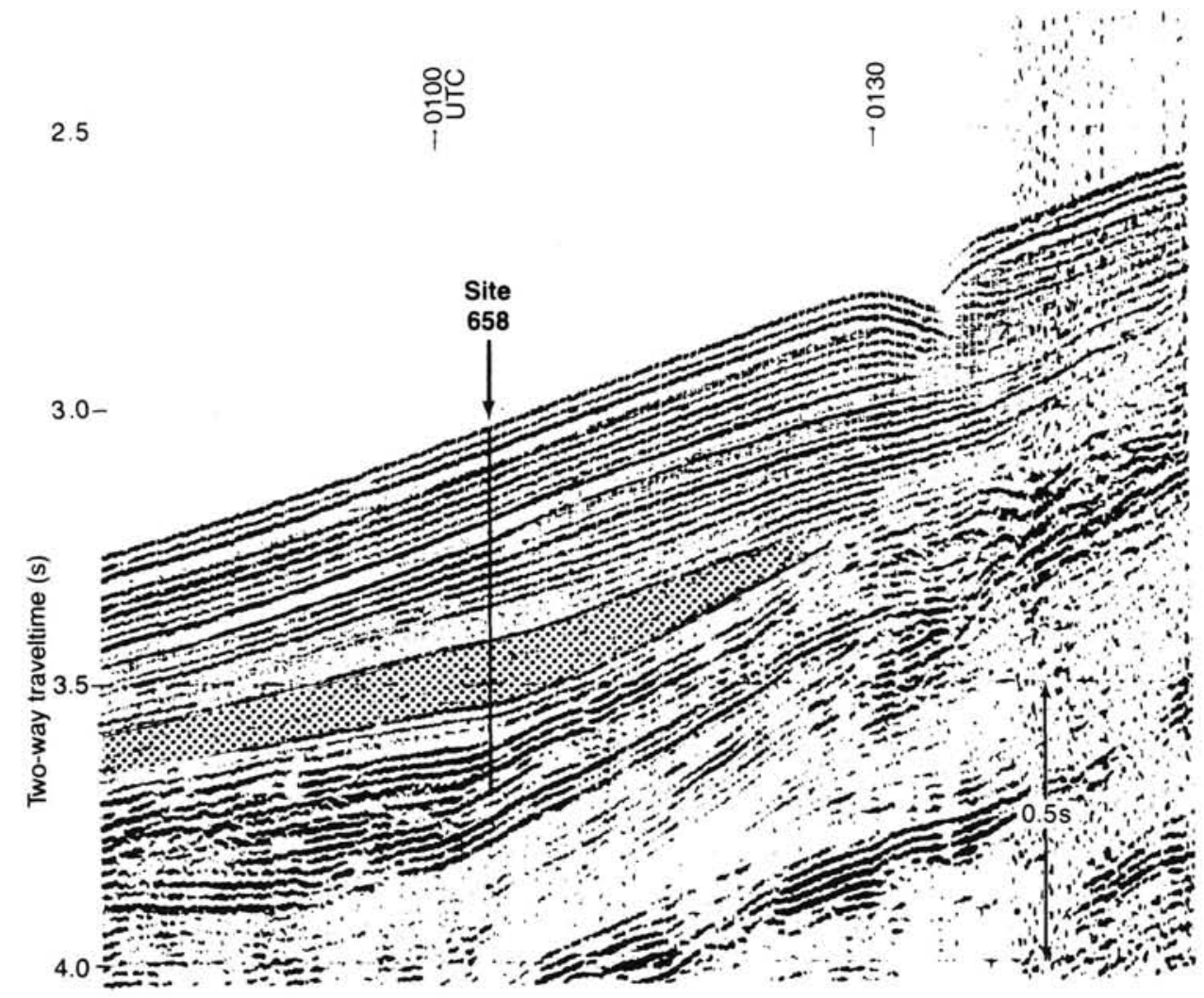

Figure 7. JOIDES Resolution seismic water gun $\left(80-\mathrm{in}^{3}\right)$ line on the approach to Site 658 . The stippled area marks an acoustic transparency zone. 
SHEAR STRENGTH $(\mathrm{kPa})$

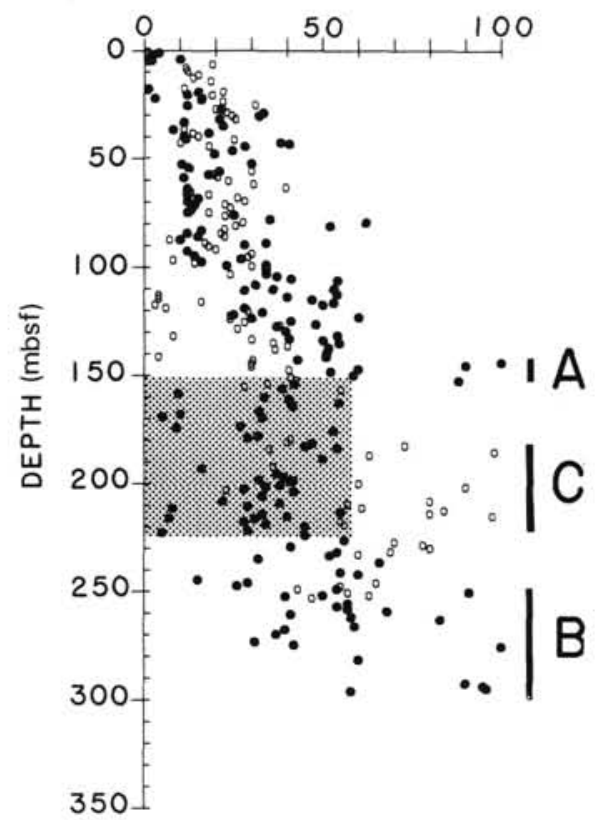

Figure 8. Shear strength vs. depth for the upwelling (solid circles, Hole 658A) and the nonupwelling site (open circles, Hole 659A). A, B, and $\mathrm{C}$ mark areas of high shear strength at Holes 658A and 659A. The stippled area marks a low shear strength zone at Hole 658A.

Infilling of a trough is also possible. However, in this case, the sediment should be reworked, which we did not observe at this particular depth interval. Considering the fact that the sedimentation rate $(108 \mathrm{~m} / \mathrm{m} . \mathrm{y}$.) is approximately constant within the cored bowl-shaped seismic unit, free gas is a likely cause of the observed acoustic feature. However, free gas is normally associated with zones of "wipe outs" (acoustic transparency zones) on seismic records, where little if any energy is returned from beneath the gas. In addition, very strong reflectors are often observed at the top of its gas layer. Neither of these conditions apply in this case; therefore, the question of free gas remains unsolved.

\section{Shear Strength}

Of all the physical properties measured at Holes $658 \mathrm{~A}$ and $659 \mathrm{~A}$, shear strength shows the most scattered values (Fig. 8). Because shear strength is by far the most sensitive value to sample disturbance (e.g., Mayer, 1982), the scattering of the data may indicate the degree of disturbance. In the case of Hole $658 \mathrm{~A}$, the scattering can be due to the degassing and the expansion of the sediment and thus core disturbance. Our careful selection of undisturbed sediment material, however, implies that the variations are also due to changes in lithology and increasing compaction with depth. Consolidation results in a steady increase in shear strength to a depth of about 150 mbsf. The rate of increase is approximately $20 \mathrm{kPa} / 100 \mathrm{~m}$ at Hole $658 \mathrm{~A}$, and it is slightly higher with approximately 25 $\mathrm{kPa} / 100 \mathrm{~m}$ at Hole $659 \mathrm{~A}$.

A closer view of the shear strength record reveals that drastic increases in shear strength occur at Hole $658 \mathrm{~A}$ between 140 and 150 mbsf (Fig. 8A) and between 250 and 300 mbsf (Fig. 8B) and at Hole 659A between 180 and 220 mbsf (Fig. 8C). The increases in shear strength between 250 and 300 mbsf (Fig. 8B, Hole 658A) are accompanied by concurrent increases in the abundance of terrigenous matter, as indicated by the high grain densities and low carbonate contents at this depth (Fig. 5). The high shear strength values $(>70 \mathrm{kPa})$ are probably due to changes in lithology (i.e., increases in the percentage of terrigenous matter and increases in clay content). Increases in clay content, for instance, could significantly increase the cohesion of sediment and thus the shear strength (Boyce, 1977).

The shear strength values at Hole $658 \mathrm{~A}$ remain low $(<60 \mathrm{kPa}$, $150-220$ mbsf) within most of the biogenic-silica-bearing section of lithologic Unit II (91-233 mbsf), with one exception at 140-150 mbsf. They increase to maximum values of about $100 \mathrm{kPa}$ at 250-300 mbsf in lithologic Unit III (Fig. 8). Low shear strength values also have been observed in biogenic-silica-rich sediments of the Pacific (e.g., Hamilton, 1964; Keller and Bennett, 1973; Mayer, 1982). These authors pointed out that the mechanical interlocking by spiny and open-structured siliceous microfossils may create a framework that may hinder consolidation processes. As a result, abnormally high values of porosity and water content, and low values of wet-bulk density and shear strength can occur in such sediments.

\section{Wet-Bulk Density, Water Content, and Porosity}

Contrasts in the shear strength curves between Holes $658 \mathrm{~A}$ and $659 \mathrm{~A}$ are substantiated by the independent results of gravimetric analysis (Fig. 9). At Hole 658A, wet-bulk density shows distinctly lower values between 130 and $200 \mathrm{mbsf}$ (Fig. 9A), which coincides with the observed low shear strength values (Fig. 8) of the biogenic-silica-bearing section. Between 130 and 200 mbsf, no distinct increase in wet-bulk density occurs (Fig. 6). Above $150 \mathrm{~m}$, a wet-bulk density gradient of about $0.12 \mathrm{~g} / \mathrm{cm}^{3} / 100 \mathrm{~m}$ exists. Below $200 \mathrm{~m}$, biogenic silica gives way to more calcareous and terrigenous sediments (Fig. 5 ), in which wet-bulk density increases rapidly from about 1.52 (200 mbsf) to $1.8 \mathrm{~g} / \mathrm{cm}^{3}$ (280 mbsf) (Fig. 9A). The low wet-bulk density values $\left(<1.6 \mathrm{~g} / \mathrm{cm}^{3}\right)$ clearly mark the biogenic-silica section, the most characteristic feature beneath the coastal upwelling cell.

Water content vs. depth and porosity vs. depth data (Figs. 9B and 9C) show only slight variations at both sites and do not distinctly record the presence of the biogenic-silica-bearing section at Hole 658A. At Hole 659A, a high wet-bulk density $\left(>1.7 \mathrm{~g} / \mathrm{cm}^{3}\right)$, a low water content $(<35 \%)$, and a low porosity $(<45 \%)$ correspond to a high content of terrigenous matter occurring at a depth greater than 150 mbsf. The depth gradient of both porosity and water content varies from about $5 \% / 100$ $\mathrm{m}$ at Hole $658 \mathrm{~A}$ to about $10 \% / 100 \mathrm{~m}$ at Hole 659A. In the following comparison, we concentrate on sediment with an age less than 3.5 m.y. $(<130$ mbsf at Hole $659 \mathrm{~A}$ and $<300$ mbsf at Hole 658A).

\section{Sedimentological and Physical Properties vs. Age}

Carbonate content, grain density, wet-bulk density, and porosity vs. age data are shown for the last 3.5 m.y. in Figure 10. During this time period, about $130 \mathrm{~m}$ of sediment accumulated at Hole 659A and about $274 \mathrm{~m}$ at Hole 658A (Ruddiman, Sarnthein, et al., 1988). Carbonate content is lower at Hole $658 \mathrm{~A}(10 \%-70 \%)$ than at Hole 659A (40\%-90\%) (Fig. 10A). At Hole $658 \mathrm{~A}$, a low average carbonate content (about $30 \%$ ) occurs between 3.5 and $3.2 \mathrm{Ma}$ and between 2.4 and $1.8 \mathrm{Ma}$, and two low erratic carbonate content values $(25 \%)$ occur at about 0.7 and $0.4 \mathrm{Ma}$.

The grain density values (Fig. 10B), except for the time interval between 3.2 and $3.5 \mathrm{Ma}$, are also low (between 2.4 and 1.8 $\mathrm{Ma}$ and at 0.7 and $0.4 \mathrm{Ma}$ ) but highly variable, indicating fluctuations in biogenous silica. Sediments of the nonupwelling area (Hole 659A) show little or no distinct 


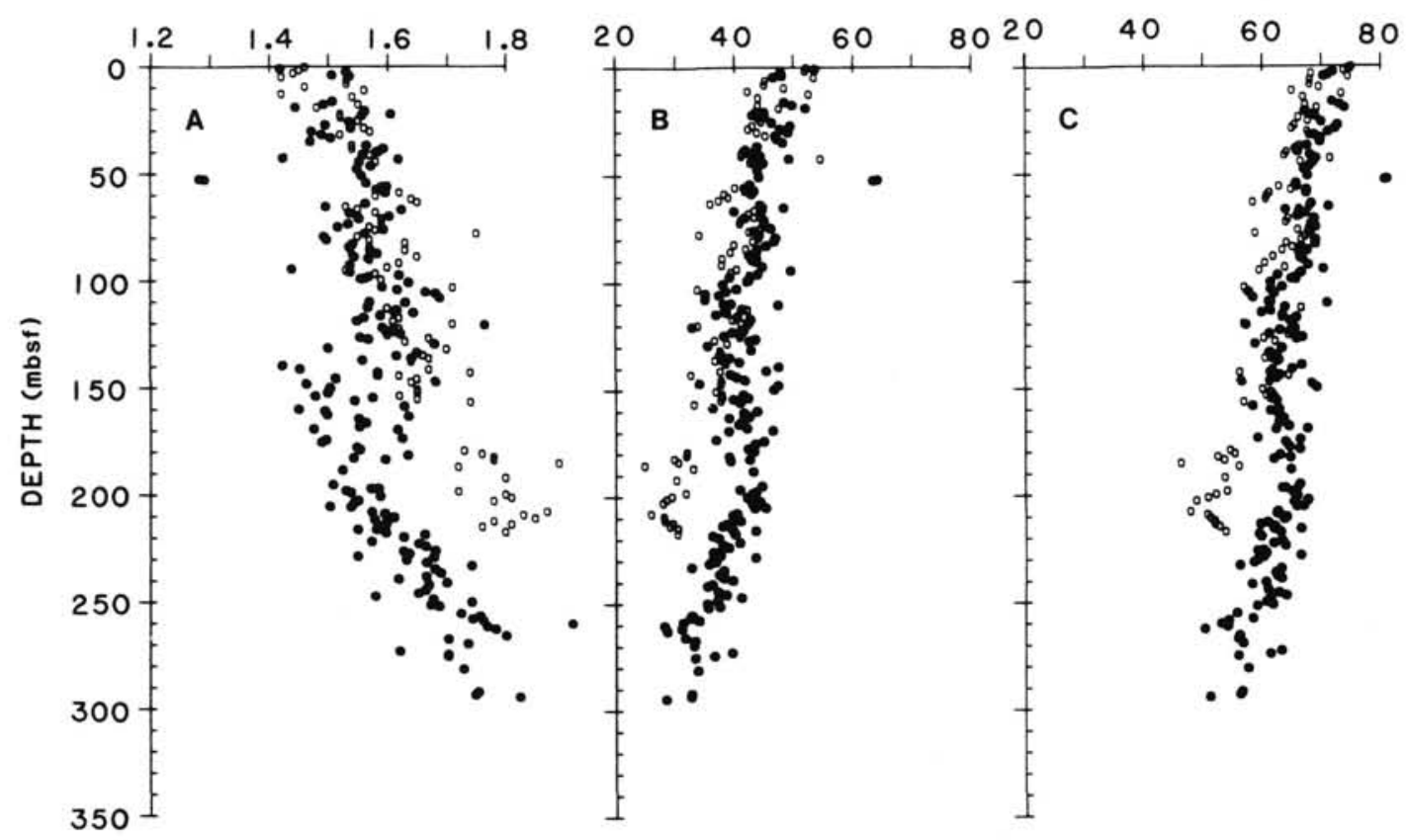

Figure 9. Wet-bulk density (A), wet-water content (B), and porosity (C) vs. depth for the upwelling (solid circles, Hole $658 \mathrm{~A}$ ) and the nonupwelling site (open circles, Hole 659A).

variation in grain density, which is expected because dilution by terrigenous matter promotes about the same grain density as pure carbonate $\left(2.65-2.75 \mathrm{~g} / \mathrm{cm}^{3}\right)$.

The differences in lithology are substantiated by the wetbulk density vs. age record (Fig. 10C). At Hole 659A, the average wet-bulk density increases with age for the time interval $<2 \mathrm{Ma}$, showing a gradient of about $0.04 \mathrm{~g} / \mathrm{cm}^{3} / \mathrm{m}$.y. It corresponds to a decrease in porosity with a gradient of about 3\%/m.y. (Fig. 10D). Superimposed on these gradients are variations in physical properties that are mainly due to changes in lithology. At Hole 658 A (Fig. 10C), for example, average wet-bulk density values decrease from $1.65 \mathrm{~g} / \mathrm{cm}^{3}$ (at $1.8 \mathrm{Ma}$ ) to $1.55 \mathrm{~g} / \mathrm{cm}^{3}$ (at $2.1 \mathrm{Ma}$ ) and continuously increase from $1.55 \mathrm{~g} / \mathrm{cm}^{3}$ (at $3 \mathrm{Ma}$ ) to a maximum value of $1.9 \mathrm{~g} / \mathrm{cm}^{3}$ (at about $3.5 \mathrm{Ma}$ ) (Fig. 10C).

The changes in wet-bulk density at Hole $658 \mathrm{~A}$ show some correspondence with decreases in carbonate content (from $50 \%$ to $30 \%$ ) at these levels (Fig. 10A). Most importantly, while the decrease in wet-bulk density corresponds to an increase in biogenous silica, the increase in wet-bulk density corresponds to an increase in terrigenous matter. Increased abundance of terrigenous matter also causes a distinct decrease in porosity from about $65 \%$ to $55 \%$ (between 3.0 and $3.5 \mathrm{Ma}$ (Fig. 10D). Thus, the most significant changes in physical properties measured at Hole 658A correspond to changes in lithology and, to a much lesser extent, to the consolidation of sediment with age and depth.

\section{CONCLUSIONS}

Distinct differences in physical properties of sediment are observed between upwelling and nonupwelling areas. The following conclusions can be drawn from our data.

1. The dominant mechanisms producing the differences in physical properties in the upper $275 \mathrm{~m}$ of sediment (for the last 3.5 m.y.), downcore and between the sites, are lithologic variations and, to a much lesser extent, consolidation processes.
2. The organic carbon content $(0 \%-3.5 \%$ over a depth from 1 to $275 \mathrm{mbsf}$ ) has no significant influence on the physical properties of sediment $(R=<0.4)$ beneath upwelling cells off northwest Africa.

3. The biogenic silica content has a profound influence on the physical properties of sediment. Low grain density, openstructured siliceous-microfossil-rich sediments at the upwelling area (Hole $658 \mathrm{~A}$ ) cause an interval with virtually no consolidation between 130 and 200 mbsf that corresponds to a low in wet-bulk density $\left(<1.6 \mathrm{~g} / \mathrm{cm}^{3}\right)$. The nonupwelling area (Hole 659A) lacks significant amounts of biogenic silica and exhibits the increasing wet-bulk density with depth that is normally associated with a consolidating sediment section. These sediments show only small variations in porosity $(3 \%)$ m.y.) and wet-bulk density $\left(0.04 \mathrm{~g} / \mathrm{cm}^{3} / \mathrm{m} . \mathrm{y}\right.$. $)$.

4. The physical properties grain density, wet-bulk density, and shear strength respond to the biogenic-silica-bearing section at a different depth (grain density $=120-180 \mathrm{mbsf}$, wet-bulk density $=130-200$ mbsf, and shear strength = 150-220 mbsf), which may indicate a distinctly different sensitivity of physical properties to changes in lithology. Certainly, such a conclusion needs further, more closely spaced sampling for studies of sediment physical properties.

5. The most substantial difference between upwelling and nonupwelling areas (Holes 658A and 659A) may be an abrupt decrease in compressional wave velocity in sediments beneath the upwelling cell, which marks the presence of biogenic gas in sediments deeper than 25 mbsf. If biogenic gas does exist in a free state in situ, then distinct changes in the compressional wave velocity will occur in situ. However, these changes cannot be measured by laboratory methods.

Although the absence of in-situ measurements of physical and, especially, acoustic properties of sediments leave large gaps in our knowledge about the acoustic environment, our laboratory data provide strong evidence that the sediment physical properties beneath upwelling cells are unique. The drastic changes in wet-bulk density at the biogenic-silica- 

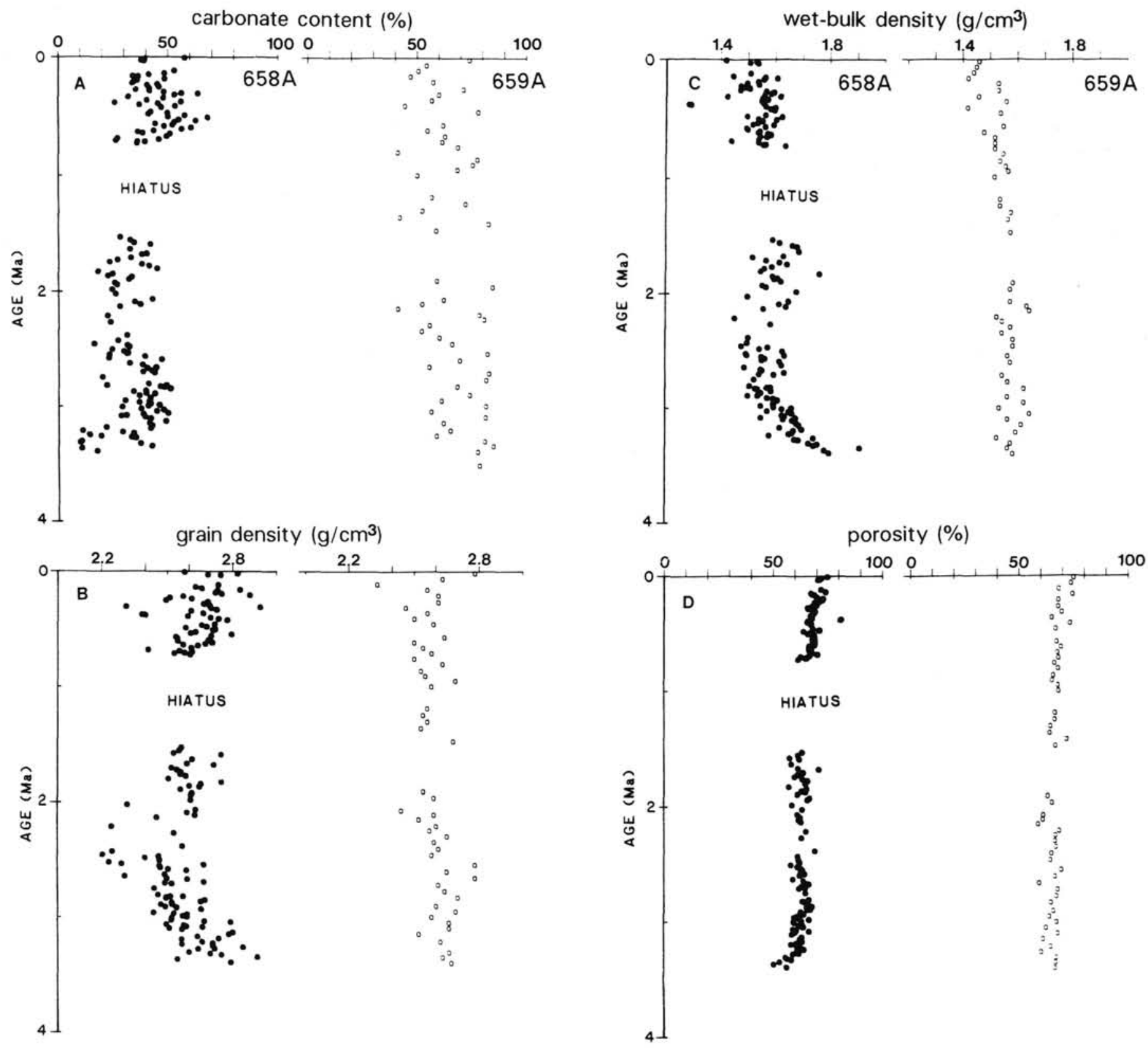

Figure 10. Carbonate content (A), grain density (B), wet-bulk density (C), and porosity (D) vs. age for the upwelling (solid circles, Hole 658A) and the nonupwelling site (open circles, Hole 659A). Age calculations are based on biostratigraphic and magnetostratigraphic data (Ruddiman, Sarnthein, et al., 88). Ages between stratigraphic markers are interpolated by a linear equation.

bearing section and the occurrence of biogenic gas in sediment cores below 25 mbsf cause a very distinct break in geotechnical properties. It should be large enough for detecting upwelling cells in sediments by acoustic methods. In the future, detailed in-situ studies of physical and acoustical properties of sediments will be invaluable for making acoustic tomography of upwelling cells visible.

\section{ACKNOWLEDGMENTS}

Drs. G. P. Lohmann, S. J. Lehman, K. Takahashi (WHOI), and B. Schwab (USGS) reviewed the initial manuscript, and we are thankful for their suggestions for improving the manuscript. The authors sincerely thank Donald Sims and Kevin Rogers for technical assistance. Travel support by the Deutsche Forschungsgemeinschaft and the Joint Oceanographic Institutions (JOI) is greatly appreciated.
Part of this work was supported by project grant 26-020136-00. This is WHOI Contribution No. 6796.

\section{REFERENCES}

Bass Becking, L.G.M., and Moore, D., 1959. Density distribution in sediments. J. Sediment. Petrol., 29:47-55.

Booth, J. S., and Dahl, A. G., 1985. A note on the relationships between organic matter and some geotechnical properties of a marine sediment. Mar. Geotechnol., 6:281-297.

Boyce, R. E., 1973. Appendix I: physical properties-methods. In Edgar, N. T., Saunders, J. B., et al., Init. Repts. DSDP, 15; Washington (U.S. Govt. Printing Office), 1115-1127. 1976. Appendix I: definitions and laboratory techniques of compressional sound velocity parameters and wet-water content, wet-bulk density, and porosity parameters by gravimetric and gamma 
ray attenuation techniques. In Schlanger, S. O., Jackson, E. D., et al., Init. Repts. DSDP, 33: Washington (U.S. Govt. Printing Office), 931-958.

, 1977. Deep Sea Drilling Project procedures for shear strength measurement of clayey sediment using modified Wykeham Farrance Laboratory vane apparatus. In Barker, P. F., Dalziel, I.W.D., et al., Init. Repts. DSDP, 36: Washington (U.S. Govt. Printing Office), 1059-1068.

Busch, W. H., and Keller, G. H., 1981. The physical properties of Peru-Chile continental margin sediments-the influence of coastal upwelling on sediment properties. J. Sediment. Petrol., 51:705-719.

Hamilton, E. L., 1964. Consolidation characteristics and related properties of sediments from Experimental Mohole (Guadalupe Site). J. Geophys. Res., 69:4257-4269.

1971. Elastic properties of marine sediments. J. Geophys. Res., 76:579-604.

Hurd, D. S., and Theyer, F., 1977. Changes in the physical and chemical properties of biogenic silica from the central equatorial Pacific: Part II. Refraction index, density, and water content of acid cleaned samples. Am. J. Sci., 227:1168-1202.

Keller, G. H., 1982. Organic matter and the geotechnical properties of submarine sediments. Geo-Mar. Lett., 2:191-198.

1983. Coastal upwelling, its influence on the geotechnical properties and stability characteristics of submarine deposits. In Thiede, J., and Suess, E. (Eds.), Coastal Upwelling: Its Sediment Record (Pt. B): New York (Plenum Press), 181-199.

Keller, G. H., and Bennett, R. H., 1973. Sediment mass physical properties-Panama Basin and northeastern equatorial Pacific. In van Andel, T. H., Heath, G. R., et al., Init. Repts. DSDP, 16: Washington (U.S. Govt. Printing Office), 499-512.

Mayer, L. A., 1982. Physical properties of sediment recovered on Deep Sea Drilling Project Leg 68 with the hydraulic piston corer. In Prell, W. L., Gardner, J. V., et al., Init. Repts. DSDP, 68: Washington (U.S. Govt. Printing Office), 365-382.

Mienert, J., Stein, R., Schultheiss, P., and Shipboard Scientific Party, 1988. Relationship between grain density and biogenic opal in sediments from Sites 658 and 660 . In Ruddiman, W., Sarnthein, M., et al., Proc. ODP, Init. Repts., 108, Sect. 2: College Station, TX (Ocean Drilling Program), 1047-1053.
Müller, P., Erlenkeuser, H., and von Gravenstein, R., 1983. Glacialinterglacial cycles in oceanic productivity inferred from organic carbon contents in eastern North Atlantic sediment cores. In Thiede, J., and Suess, E. (Eds.), Coastal Upwelling: Its Sediment Record (Pt. B): New York (Plenum Press), 365-398.

Ruddiman, W., Sarnthein, M., et al., 1988. Proc. ODP, Init. Repts., 108: College Station, TX (Ocean Drilling Program).

Sarnthein, M., Thiede, J., Pflaumann, U., Erlenkeuser, H., Fütterer, D., Koopman, B., Lange, H., and Seibold, E., 1982. Atmospheric and oceanic circulation patterns off northwest Africa during the past 25 million years. In von Rad, U., Hinz, K., Sarnthein, M., and Seibold, E. (Eds.), Geology of the Northwest African Continental Margin: Berlin-Heidelberg-New York (Springer-Verlag), $545-603$.

Shipboard Scientific Party, 1988a. Site 658. In Ruddiman, W., Sarnthein, M., et al., Proc. ODP, Init. Repts., 108, Sect. 1: College Station, TX (Ocean Drilling Program), 105-219.

Shipboard Scientific Party, 1988b. Site 659. In Ruddiman, W., Sarnthein, M., et al., Proc. ODP, Init. Repts., 108, Sect. 1: College Station, TX (Ocean Drilling Program), 221-325.

Stein, R., and Sarnthein, M., 1984. Late Neogene events of atmospheric and oceanic circulation patterns offshore northwest Africa: high-resolution record from deep-sea sediments. Paleoecol. Afr., 16:9-36.

Suess, E., and Müller, P. J., 1980. Productivity, sedimentation rate and sedimentary organic matter in the oceans. II. Elemental fractionation. Colloq. Int. CNRS Biogéochem. Mat. Organ. l'Interface Sed. Mar., 293:17-26.

Thiede, J., Suess, E., and Müller, P., 1982. Late Quaternary fluxes of major sediment components to the sea floor at the northwest African continental slope. In von Rad, U., Hinz., K., Sarnthein, M., and Seibold, E. (Eds.), Geology of the Northwest African Continental Margin: Berlin-Heidelberg-New York (Springer-Verlag), 605-631.

Date of initial receipt: 23 May 1988

Date of acceptance: 16 December 1988

Ms 108B-149 